\title{
PEMODELAN PERUBAHAN PENGGUNAAN LAHAN - CELLULAR AUTOMATA DI KECAMATAN ASEMROWO, KOTA SURABAYA
}

\author{
Widiyanto Hari Subagyo Widodo', Annisaa Hamidah Imaduddina², \\ 1,2Perencanaan Wilayah dan Kota, Institut Teknologi Nasional (ITN) Malang \\ Email: nisa_pwk@yahoo.com
}

\section{INFO ARTIKEL}

Riwayat Artikel:

Diterima: 04-12-2017

Disetujui: 08-01-2018

\section{Kata Kunci:}

Land

Markov

Chain

Cellular

Automata

\section{A. LATAR BELAKANG}

Pembangunan berkelanjutan merupakan proses pembangunan lahan, kota, bisnis maupun masyarakat yang berprinsip untuk memnuhi kebutuhan saat ini tanpa mengorbankan kebutuhan generasi masa depan.

\begin{abstract}
Abstrak: Kecamatan Asemrowo memiliki perkembangan yang stagnan karena adanya pengaruh dari genang pasang air laut yang mengakibatkan penurunan nilai lahan (RDTRK UP Tambak Osowilangun, 2007). Kondisi struktur dan mofologi kota yang stagnan berpotensi untuk berubah karena adanya pembangunan pusat pertumbuhan baru yaitu Pelabuhan Teluk Lamong (Pelindo III). Penelitian ini bertujuan untuk memprediksi penggunaan lahan ke depan dengan mengakomodasikan faktor penghambat berupa genang pasang air laut dan faktor pendorong (Pelabuhan Pelindo III) menggunakan metode Markov - cellular automata.

Markov- cellular automata adalah salah satu jenis kecerdasan buatan dengan dasar perhitungan iterasi pada data raster. Iterasi tersebut dilakukan pada data raster probabilitas perubahan penggunaan lahan yang diformulasikan dari multi-faktor pendorong perubahan penggunaan lahan dan penghambat perubahan penggunaan lahan. Jumlah piksel yang menjadi acuan dalam proses iterasi dianalisis dengan menggunaan analisis Markov. Dalam merumuskan peta probabilitas perubahan penggunaan lahan digunakan metode regresi logistik dan jaringan saraf tiruan. Tahun akhir prediksi penggunan lahan adalah 2030.

Hasil penelitian menunjukkan genang pasang air laut memiliki korelasi positif terhadap perubahan penggunaan lahan menjadi industri pergudangan, permukiman desa, dan tambak yaitu sebesar $21 \%, 20 \%$ dan $22 \%$.
\end{abstract}

\begin{abstract}
Asemrowo is a district with a stagnant growth due to tidal inundation which caused decreasing land value. However, the area has set to be a new growth center by large-scale development of Teluk Lamong Bay Port (Pelindo III) which consider as a driving force to change urban structure as well as urban morphology. This interesting fact finding is important for further study. This study aims to predict future land use that accommodates coastal inundation and urban driving force. The land use modelling employs Markov-cellular automata, since it promotes raster data with specified iteration process. There are many advantages to applying cellular automata models to urban systems: realism, spatiality, resolution, presentation, and links with geographic information systems, object-oriented programming, and remotely sensed data. The preliminary finding has generated the land use scenario from 2013-2030. Based upon the preliminary findings, tidal inundation has a positive correlation with land use change, especially from settlements to industrial areas, shrubs to industrial area, shrubs to fishponds, fishpond to industrial area. This means that large-scale development of Pelindo III give positive correlation towards future urban structure and urban morphology. In fact, most of the changes tend to be industrial area. Based on the model in year 2030, number area changes in total; urban facilities (+) $2.348 \mathrm{~m}^{2}$, industrial area (+) $2.379 .720 \mathrm{~m}^{2}$, trade and services area (+) $227.709 \mathrm{~m}^{2}$, settlement area (+) $19.480 \mathrm{~m}^{2}$, green open space (-) $167 \mathrm{~m}^{2}$, shrubs (-) 1.507 .690 $\mathrm{m}^{2}$ and fishponds (-) $848.044 \mathrm{~m}^{2}$. In conclusion, using Markov-Cellular Automata makes possible for scholar to conduct future modelling of land use by accommodating constraint and driving force
\end{abstract}

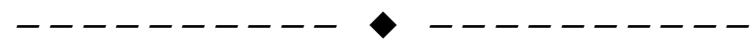

Isu lingkungan merupakan isu strategis dalam pembangunan wilayah pesisir. Pertumbuhan penduduk yang pesat di kawasan pesisir meningkatkan kebutuhan ruang untuk mewadahi kegiatan manusia. Adanya tekanan dari alam dapat berdampak negatif terhadap 
alokasi lahan potensial dalam memenuhi kebutuhan lahan. Genang pasang air laut sebagai eksternalitas negatif dari lingkungan berdampak signifikan terhadap penurunan nilai lahan, daerah yang memiliki histori bencana cenderung menurunkan nilai lahan (Yunus, 2008) [1]. Potensi genangan pasang air laut merupakan ancaman bencana yang serius bagi kota - kota di kawasan pesisir karena kawasan pesisir menjadi tempat bermuaranya sungai-sungai dan merupakan dataran rendah yang elevasi muka tanahnya sama dengan elevasi air laut pasang rata-rata ( Marfai dan King, 2008)

Kecamatan Asemrowo merupakan kecamatan pesisir di Kota Surabaya yang memiliki fungsi kegiatan sebagai pelabuhan, permukiman, perdagangan jasa dan Industri. Keadaan topografi Kecamatan Asemrowo yang berada pada ketinggian o-4 meter diatas permukaan air laut mengakibatkan Kecamatan Asemrowo berpotensi terhadap genangan pasang air laut. Adanya pengaruh genangan pasang air laut berdampak pada perkembangan fungsi kegiatan yang ada sehingga mengakibatkan adanya penurunan nilai lahan dan kecenderungan wilayah ini untuk tidak berkembang.

Berdasarkan Kondisi tersebut perlu dikaji lebih lanjut bagaimana pengaruh genang pasang dan rencana pembangunan infrastruktur pada alokasi ruang di Kecamatan Asemrowo. Penelitian ini akan melakukan pemodelan prediksi penggunaan lahan yang mengakomodasikan permasalahan $\mathrm{di}$ atas guna mengetahui ukuran, spasial, temporal dan visualisasi untuk merumuskan perencanaan yang berkelanjutan. Sehingga apabila terjadi potensi penyimpangan dari penggunaan lahan jika dibandingkan dengan RDTRK UP Tambak Osowilangun (2007), dapat menjadi masukan bagi pemerintah guna merumuskan kebijakan tata ruang yang berkelanjutan [2].

\section{B. METODE PENELITIAN}

Metode analisis yang digunakan memprediksi perubahan penggunaan lahan di Kecamatan Asemrowo dilakukan dalam empat sasaran penelitian. Berikut adalah penjabaranya :

\section{Prediksi Distribusi Genangan Pasang Air Laut}

Tahap pertama adalah tahap pemodelan persebaran distribusi genangan pasang pada tahun 2013 dan prediksi distribusi genang pasang air laut tahun 2030. Analisis terkait prediksi distribusi genang pasang air laut menggunakan dua data yaitu HHWL dan DEM. Hasil analisis pada tahap ini akan digunakan dalam analisis peta probabilitas perubahan penggunaan lahan sebagai faktor penghambat perubahan penggunaan lahan.

\section{Faktor-Faktor yang berpengaruh terhadap Perubahan Penggunaan Lahan}

Tahap kedua adalah mengidentifikasi faktor yang berpengaruh terhadap perubahan penggunaan lahan. Identifikasi faktor dilakukan dengan menggunakan analisis v-cramer's dengan menggunakan alat analisis idrisi 17.o. Analisis ini dilakukan pada setiap perubahan penggunaan lahan yang teridentifikasi di Kecamatan Asemrowo periode 2002 - 2010. Dalam prediksi perubahan penggunaan lahan, selain diperlukan analisis faktor yang berpengaruh terhadap perubahan pernggunaan lahan diperlukan juga analisis terkait kecenderungan perubahan penggunaan lahan.

\section{Kecenderungan Perubahan Penggunaan Lahan}

Tahap ketiga dalam penelitian ini adalah analisis kecenderungan perubahan penggunaan lahan untuk mengetahui jenis perubahan penggunaan lahan yang terjadi serta arah dari perubahan penggunaan lahan tersebut. Analisis probabilitas perubahan penggunaan lahan juga dilakukan pada tahap ketiga ini. Analisis ini berguna untuk mengetahui area yang memiliki potensi untuk mengalami perubahan penggunana lahan. Analisis probabilitas perubahan penggunaan lahan ini dilakukan pada tiap jenis perubahan penggunaan lahan yang teridentifikasi.

\section{Perubahan Penggunaan Lahan}

Hasil analisis tahap I, II dan III digunakan sebagai dasar dalam analisis perubahan penggunaan lahan. Jadi dapat disimpulkan dalam analisis perubahan penggunaan lahan diperlukan tiga data inti yaitu faktor yang berpengaruh terhadap perubahan penggunaan lahan, kecenderungan perubahan penggunaan lahan dan probabilitas perubahan penggunaan lahan. Gambar 1 menyajikan penjelasan mengenai metode analisis dan penjabaran dari analisis yang digunakan berdasarkan tujuan penelitian.

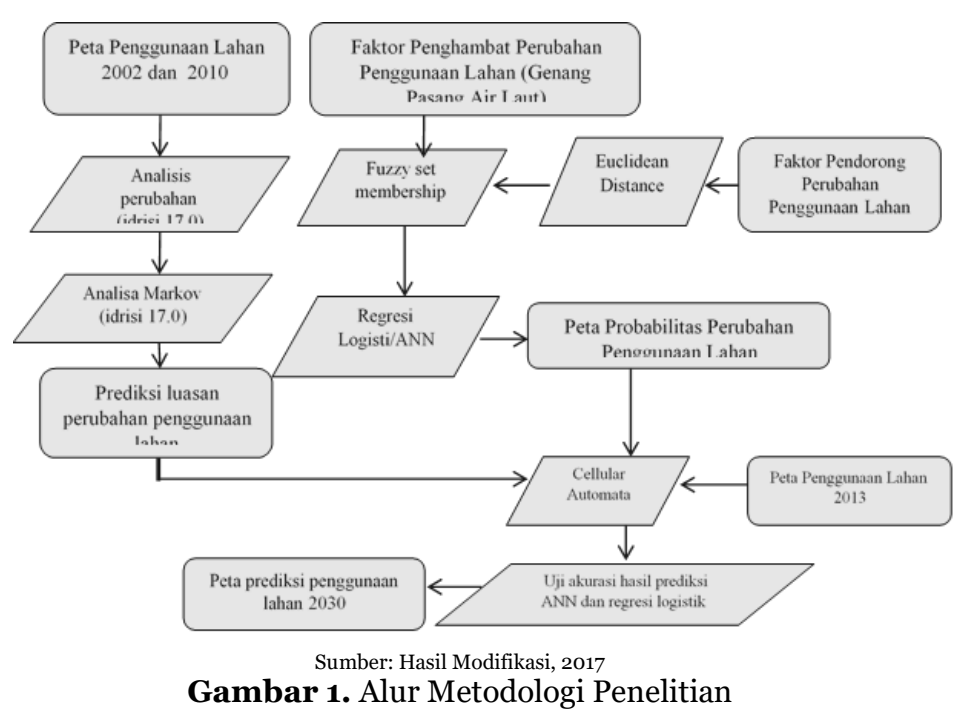

\section{HASIL DAN PEMBAHASAN}

Ketinggian genangan pasang maksimum yang terjadi di Kecamatan Asemrowo pada tahun 2013 teridentifikasi 
sebesar 1,7 meter dengan luas area terdampak sebesar $45 \%$ dari luas wilayah Kecamatan Asemrowo atau sebesar 319 ha. Pada tahun 2030 diprediksikan bahwa laju kenaikan muka air laut akan meningkat sebesar 0,094 $\mathrm{cm}$ dengan laju kenaikan air laut rata-rata 4,8 $\mathrm{mm} /$ tahun. Adanya peningkatan muka air laut ini berdampak pada semakin luasnya area genangan pasang air laut di Kecamatan Asemrowo. Pada tahun 2030 teridentifikasi ketinggian genangan pasang air laut meningkat menjadi 1,8 meter dengan luas area terdampak sebesar $49 \%$ dari luas wilayah Kecamatan Asemrowo atau sebesar 320 ha. Dari hasil tersebut diketahui bahwa, dengan peningkatan kenaikan muka air laut sebesar 0,094 $\mathrm{cm}$ dapat meningkatkan luas genangan pasang sebesar 1 ha dalam kurung waktu 17 tahun. Jika dikorelasikan dengan penggunaan lahan, mayoritas penggunaan lahan yang terkena genangan pasang air laut adalah industri pergudangan (47\%) dan tambak (21\%). Berikut adalah gambar distribusi spasial genangan pasang air laut di Kecamatan Asemrowo tahun 2013 dan 2030
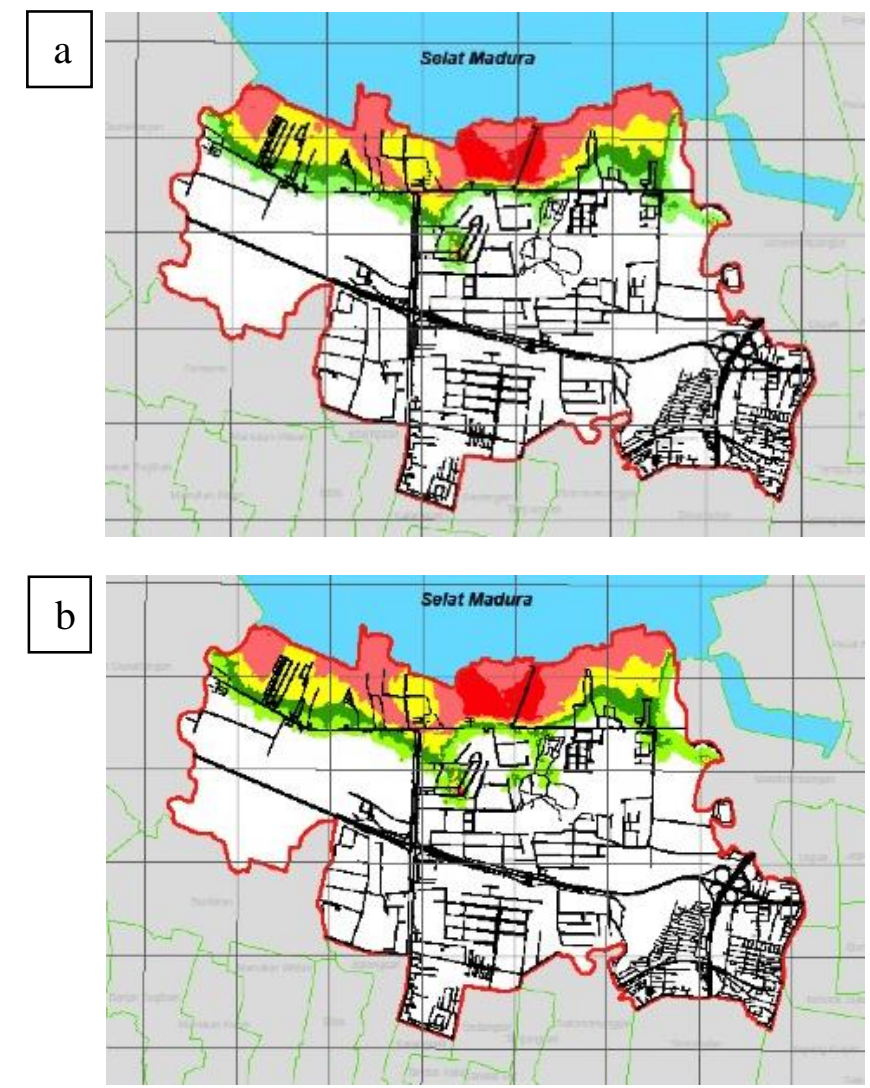

Gambar 2. Genang Pasang (a) Tahun 2016, (b) Tahun 2030

Sumber : Hasil Analisis, 2017

Berdasarkan analisa faktor yang dilakukan menggunakan nilai v-cramers diketahui bahwa kedalaman genangan pasang di Kecamatan Asemrowo berpengaruh pada pola perubahan penggunaan lahan. Penggunaan lahan yang akan berpengaruh terhadap kedalaman genangan pasang adalah permukiman kota, industri dan pergudangan, tambak dan permukiman pedesaan. Selain genangan pasang air laut, faktor-faktor yang mendorong perubahan penggunaan lahan adalah jarak dari jaringan jalan, jarak dari fasilitas perkotaan, jarak dari CBD, jarak dari pusat perdagangan dan jasa, jarak dari pusat industri, jarak dari titik pertemuan sistem jalan, dan jarak dari pelabuhan.

Prediksi penggunaan lahan dibagi menjadi tiga tahap yaitu tahap pembuatan peta probabilitas perubahan penggunaan lahan, prediksi perubahan piksel dari tiap kelas penggunaan lahan dan prediksi perubahan penggunaan lahan. Berdasarkan hasil analisis regresi logistik dan jaringan saraf tiruan yang digunakan untuk merumukan peta probabilitas penggunaan lahan selanjutnya akan dianalisis tahap pemodelan prediksi perubahan penggunaan lahan digunakan metode cellular automata. Dalam tahap pemodelan prediksi perubahan penggunaan lahan digunakan metode cellular automata dengan alat analisis idrisi 17.o. Dalam analisis ini menggunakan tiga data., berikut merupakan tiga data yang digunakan dalam analisis ini.

a. Peta dasar penggunaan lahan : adapun dalam penelitian ini adalah peta penggunaan lahan tahun 2013 sebagai data multitemporal terakhir

b. Peta probabilitas penggunaan lahan: peta probabilitas perubahan penggunaan lahan dari hasil spasial regresi logistik dan analisis jaringan saraf tiruan (neural network).

c. Jumlah piksel lahan yang berubah: hasil prediksi perubahan piksel dari setiap kelas penggunaan lahan tahun 2030. Peta yang menjadi acuan prediksi adalah peta 2002 dan 2010.

Prediksi yang akan dilakukan dengan menggunakan data acuan 2002 dan 2010 memiliki dua tahun proyeksi yaitu tahun 2013 dan tahun 2030. Prediksi penggunaan lahan tahun 2013 (waktu saat penelitian berlangsung) dilakukan untuk keperluan uji model. Uji validasi ini ditujukan untuk mengetahui akurasi dan tingkat validasi peta hasil pemodelan, dalam uji validasi akan dibanding nilai indeks kappa dari pemodelan cellular automata yang diintegrasikan dengan regresi logistik dan pemodelan cellular automata yang diintegrasikan dengan jaringan saraf tiruan (neural network). Peta yang memiliki nilai indeks kappa tertinggi merupakan metode yang digunakan untuk menghasilkan peta prediksi penggunaan lahan tahun 2030. Berdasarkan nilai indeks kappa yang teridentifikasi, dapat disimpulkan bahwa prediksi penggunaan lahan dengan menggunakan data yang diekstraksi dari metode regresi logistik dapat dikategorikan valid. Hasil analisis ini dapat dikatakan valid karena nilai indeks kappanya $(90 \%) \geq 85 \%$. Jika dikomparasikan dengan prediksi penggunaan lahan dengan menggunakan data yang diekstraksi dari metode jaringan saraf tiruan (neural network), metode ini dikatergorikan tidak valid karena nilai indeks kappa yang teridentifikasi $(84 \%) \leq 85 \%$. Jadi dalam penelitian ini dalam memprediksi penggunaan lahan Kecamatan Asemrowo tahun 2030 
menggunakan data peta probabilitas perubahan penggunaan lahan yang dihasilkan dari analisis regresi logistik. Gambar 3 menyajikan hasil pola perubahan penggunaan lahan Kecamatan Asemrowo tahun 2002, 2010, 2013 dan 2030.
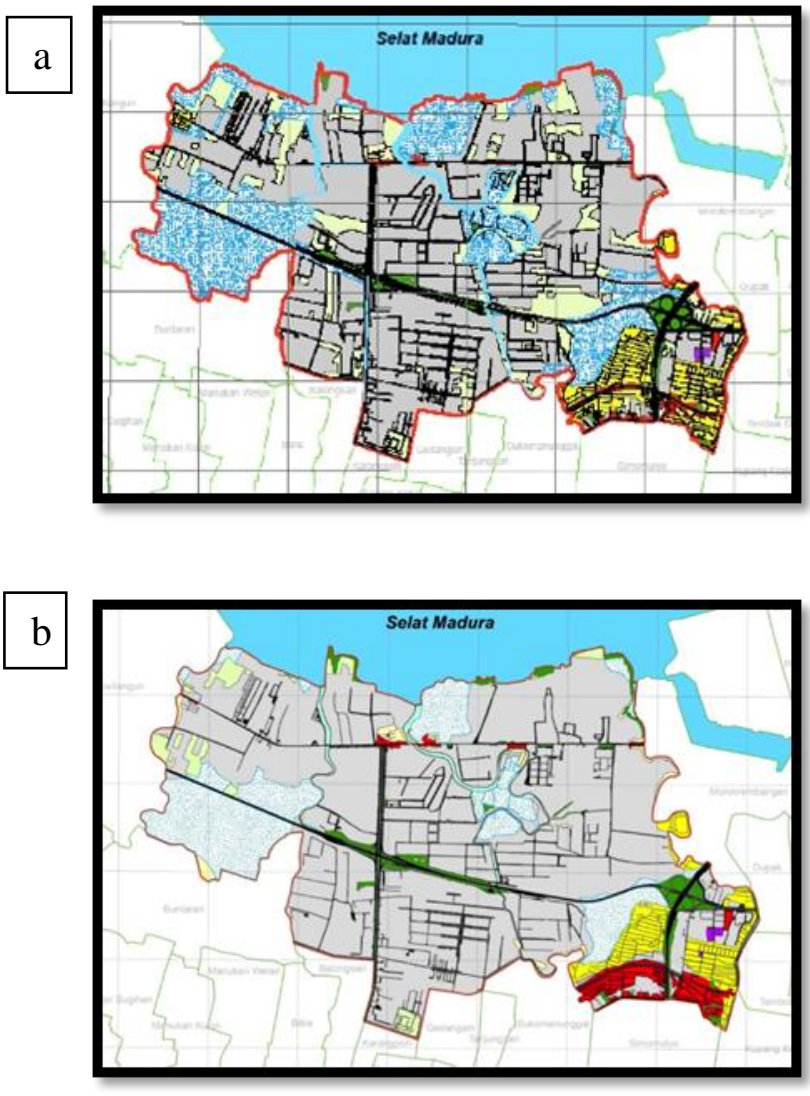

Sumber : Hasil Analisis,2017

Gambar 3. Pola Perubahan Penggunaan Lahan (a) Tahun 2013; (b) Tahun 2030.

Berdasarkan peta hasil prediksi penggunaan lahan di Kecamatan Asemrowo tahun 2030, teridentifikasi bahwa perubahan penggunaan lahan menjadi industri dan pergudangan mendominasi perubahan penggunaan lahan. Untuk lebih jelasnya mengenai perubahan penggunaan lahan di Kecamatan Asemrowo, Berikut merupakan Gambar 4 yang menyajikan luas penggunaan lahan di Kecamatan Asemrowo pada tahun 2030.

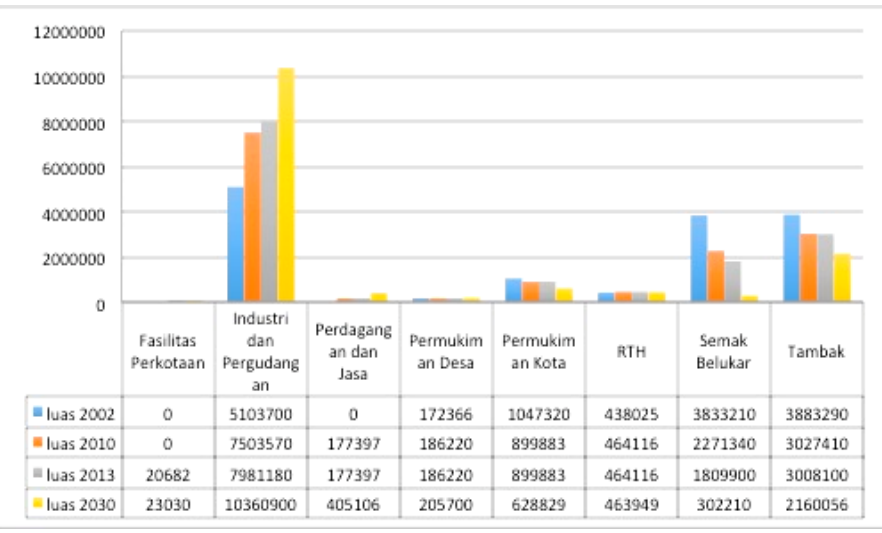

Gambar 4. Pola Perubahan Penggunaan Lahan 20022030 di Kecamatan Asemrowo
Berdasarkan tabel diatas diketahui bahwa $71 \%$ penggunaan lahan di Kecamatan Asemrowo adalah industri dan pergudangan. Kawasan industri dan pergudangan mengalami peningkatan pada setiap tahunnya. Pada tahun 2030 diprediksikan luas industri dan pergudangan akan meningkat meningkat sebesar $23,79 \%$.

\section{SIMPULAN DAN SARAN}

Berdasarkan kondisi wilayah studi dan hasil Analisis yang telah dilakukukan, Berikut merupakan kesimpulan yang disintesakan.

1. Genangan pasang air laut pada tahun 2013 memiliki rentang nilai o m sampai dengan $1,73 \mathrm{~m}$. Sedangkan pada tahun 2030 genangan pasang air laut memiliki rentang nilai $\mathrm{o} \quad \mathrm{m}$ sampai dengan $1,88 \mathrm{~m}$. Peningkatan ketinggian tersebut diikuti dengan pertambahan luas area tergenang yaitu sebesar $180.510 \mathrm{~m}$. Hal tersebut berpotensi untuk meningkatkan potensi resiko genang pasang air laut di Kecamatan Asemrowo

2. Laju pertumbuhan tertinggi teridentifikasi pada penggunaan lahan industri pergudangan yaitu sebesar 139.983,53 $\mathrm{m}^{2} /$ tahun. Secara lengkap laju pertumbuhan yang teridentifikasi meningkat adalah fasilitas perkotaan $\left(138,11 \mathrm{~m}^{2} /\right.$ tahun), perdagangan dan jasa (133.94,65 $\mathrm{m}^{2} /$ tahun), permukiman desa $\left(1.145,87 \mathrm{~m}^{2} /\right.$ tahun) dan laju pertumbuhan perubahan penggunaan lahan yang teridentifikasi menurun adalah permukiman kota (159.44,34 $\mathrm{m}^{2} /$ tahun), RTH (9,81 $\mathrm{m}^{2} /$ tahun), semak belukar $\left(88.687,65 \mathrm{~m}^{2} /\right.$ tahun $)$ dan tambak (49.884,93 $\mathrm{m}^{2} /$ tahun).

3. Genang pasang air laut memiliki korelasi positif terhadap perubahan penggunaan lahan permukiman kota - industri dan pergudangan, semak belukar industri pergudangan, semak belukar - permukiman desa, semak belukar - tambak, tambak - industri pergudangan, tambak - permukiman desa. Jadi dapat disimpulkan bahwa genang pasang air laut memiliki pengaruh yang signifikan terhadap perubahan penggunaan lahan di Kecamatan Asemrowo. Sedangkan Pelabuhan rencana yaitu Pelabuhan Teluk Lamong memiliki korelasi positif terhadap perubahan penggunaan menjadi permukiman kota dan industri dan pergudangan. Jadi dapat disimpulkan bahwa genang pasang air laut memiliki pengaruh yang signifikan terhadap perubahan penggunaan lahan di Kecamatan Asemrowo

4. Penggunaan lahan industri pergudangan mendominasi penggunaan lahan Kecamatan Asemrowo sebesar $69 \%$ dari total luas wilayah Kecamatan Asemrowo pada tahun 2030. Dominasi industri pergudangan ini merupakan pengaruh dari kebijkan pemerintah yaitu pembangunan Pelabuhan Teluk Lamong. Teridentifikasi juga potensi 
penyimpangan dari rencana pola ruang UP Tambak Osowilangun jika dikomparasikan dengan kecenderungan perubahan penggunaan lahan. Hal tersebut terjadi karena dalam perumusan rencana pola ruang tidak mengakomodasikan kecenderungan perubahan penggunaan lahan baik berupa arah ataupun luas.

\section{UCAPAN TERIMA KASIH}

Tim penulis mengucapkan terimakasih kepada Prodi Perencanaan Wilayah dan Kota ITN Malang atas dukungan dalam sumbangsih pemikiran untuk mnyempurnakan penelitian ini.

\section{DAFTAR RUJUKAN}

\section{BUKU}

[1] Yunus, H.S. 2008. Struktur Tata Ruang Kota. Yogyakarta:Pustaka Pelajar

[2] Anonim. 2007. Rencana Detail Tata Ruang Kawasan Tambak Oso Wilangun Tahun 2007-2027. Surabaya: Bappeko Surabaya

\section{JURNAL}

[3] Marfai et al. 20o8. Potential vulnerability implication of coastal inundation due to sea level rise for the coastal zone of Semarang City, Indonesia. Environmental Geology. DOI 10.1007/s00254-007-0906-4. 11. Vol. 54, Page 1235-1245

\section{PROFIL PENULIS UTAMA}

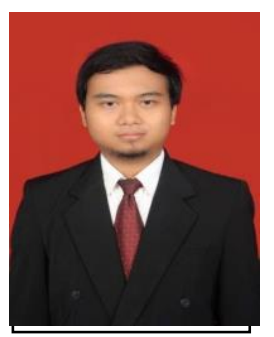

Widiyanto Hari Subagyo Widodo, lahir pada 4 Maret 1989 di Kota Bandung, Jawa Barat. Penulis menempuh pendidikan sarjana di jurusan perencanaan wilayah dan Kota, Institut Teknologi Sepuluh Nopember (ITS) Surabaya kemudian melanjutkan pendidikan master di Universitas Gadjah Mada Yogyakarta, mengambil jurusan geo-information for spatial planning and risk management.

Saat ini penulis aktif sebagai dosen di Jurusan Perencanaan Wilayah dan Kota, Institut Teknologi Nasional (ITN) Malang. Penulis juga tergabung dalam Ikatan Ahli Bencana (IAB) dan menjadi pengurus di Jawa Timur pada kelompok kerja gelombang ekstrim dan kekeringan.

Penulis juga aktif dalam penelitian, pengabdian masyarakat dan kerjasama dengan pemerintah terkait kebencanaan. Penelitian yang pernah dilakukan salah satunya adalah mengenai permodelan banjir genang pasang air laut di Kota Surabaya. Selain itu penulis juga turut membantu Kementerian Agraria dan Tata Ruang dalam menyusun pemetaan kawasan rawan bencana di seluruh Kabupateb/Kota Pantai selatan Jawa dan menyusun rencana Kota tangguh bencana 7 Kota di Indonesia. 